\title{
The role of complement in the tumor microenvironment
}

\author{
Danyaal Ain ${ }^{1, \mathrm{x}} \quad$ Talha Shaikh $^{1, \mathrm{x}} \quad$ Samantha Manimala ${ }^{1, \mathrm{x}} \quad$ Berhane Ghebrehiwet ${ }^{1^{*}}$ \\ ${ }^{1}$ The Department of Medicine, Stony Brook University, 100 Nicholls Road, Stony Brook, NY 11794-8161, USA \\ ${ }^{\mathrm{x}}$ Equal contributors
}

\begin{abstract}
Tumorigenesis has long been linked to the evasion of the immune system and the uncontrolled proliferation of transformed cells. The complement system, a major arm of innate immunity, is a key factor in the progression of cancer because many of its components have critical regulatory roles in the tumor microenvironment. For example, complement anaphylatoxins directly and indirectly inhibit antitumor T-cell responses in primary and metastatic sites, enhance proliferation of tumor cells, and promote metastasis and tumor angiogenesis. Many recent studies have provided evidence that cancer is able to hijack the immunoregulatory components of the complement system which fundamentally are tasked with protecting the body against abnormal cells and pathogens. Indeed, recent evidence shows that many types of cancer use $\mathrm{C} 1 \mathrm{q}$ receptors $(\mathrm{C} 1 \mathrm{qRs})$ to promote tumor growth and progression. More importantly, most cancer cells express both $\mathrm{C} 1 \mathrm{q}$ and its major receptors (gC1qR and cC1qR) on their surface which are essential for cell proliferation and survival. In this review, we discuss the ability of cancer to control and manipulate the complement system in the tumor microenvironment and identify possible therapeutic targets, including $\mathrm{C} 1 \mathrm{q}$ and gC1qR.
\end{abstract}

\section{Keywords}

complement, activation fragments, $\mathrm{gC} 1 \mathrm{qR}$

\section{Peer Review}

The peer reviewers who approve this article are:

1. Raphael A Nemenoff, Division of Nephrology and Hypertension, University of Colorado Anschutz Medical Campus, Aurora, CO, USA

Competing interests: No competing interests were disclosed.

2. Maciej M Markiewski, Department of Immunotherapeutics and Biotechnology, School of Pharmacy, Texas Tech University Health Sciences Center, Abilene, TX, USA

Competing interests: No competing interests were disclosed. 
*Corresponding author: Berhane Ghebrehiwet (berhane.ghebrehiwet@stonybrook.edu)

Competing interests: The authors declare that they have no competing interests.

Grant information: The work included in this article was supported in part by grants from the National Institutes of Allergy and Infectious Diseases

(R01 AI 060866 and R01 AI-084178 to BG).

The funders had no role in study design, data collection and analysis, decision to publish, or preparation of the manuscript.

Copyright: (C) 2021 Ghebrehiwet B et al. This is an open access article distributed under the terms of the Creative Commons Attribution License, which permits unrestricted use, distribution, and reproduction in any medium, provided the original work is properly cited.

How to cite this article: Ain D, Shaikh T, Manimala S and Ghebrehiwet B. The role of complement in the tumor microenvironment. Faculty Reviews 2021 10:(80) https://doi.org/10.12703/r/10-80

Published: 29 Nov 2021, Faculty Reviews 10:(80) https://doi.org/10.12703/r/10-80 


\section{Introduction}

What is cancer?

Cancer can be defined as the autonomous growth of transformed cells, which eventually leads to the formation of masses called tumors. Generally, healthy cells have checkpoints and mechanisms to maintain their cycle of growth and performance. Cancer cells, however, have lost the ability to stop growing when necessary and this can be quite dangerous given that cells endure non-beneficial genetic changes over their lifetime'. Three distinct features of cancer are immune invasion, angiogenesis, and metastasis. These hallmarks can be expanded and compartmentalized into features such as proliferative signaling, growth suppressors evasion, apoptosis or programmed cell death resistance, angiogenesis, and metastasis or invasion activation $^{2}$. In order to enhance their growth and survival, tumor cells can promote the progression of the cancer by using a tumorassociated stroma, which in turn consists of recruited cells and host cells of the infiltrated tissue. Multiple stromal cell types, along with other cells and proteins in the environment of the tumor, make up the tumor cell microenvironment, which essentially sustains and protects the growing cancerous mass ${ }^{2}$. Complement proteins interact with proteins in the tumor cell microenvironment and play a role in many of the hallmarks of cancer, such as immunosuppression, angiogenesis, inhibition of apoptosis, and effective immune evasion.

\section{The role of complement in immunity}

The complement system is a well-orchestrated and highly regulated biological system and consists of three independent but interactive pathways (Figure 1). Although each pathway is activated by target-specific antibodies or by structural elements on the target cell or pathogen, they all converge at the level of $\mathrm{C} 3$, which is cleaved by $\mathrm{C} 3$ convertase to generate $\mathrm{C} 3 \mathrm{~b}$. Once the $\mathrm{C} 3 \mathrm{~b}$ is membrane-bound, the sequential recruitment and activation of $\mathrm{C} 5$ followed by the assembly of the terminal complement proteins $\mathrm{C} 5 \mathrm{~b}-\mathrm{C} 9$ complex or membrane attack complex (MAC) are common to all three pathways. Once MAC is assembled on the pathogen or cell surface, the target cell is destroyed by osmotic lysis in a manner similar to the cell lysis caused by the pore forming cytolytic protein perforin, which is found in the granules of cytotoxic $\mathrm{T}$ lymphocytes and natural killer cells.

The classical complement pathway is activated when antibody-antigen complexes are formed on bacterial or cell surfaces. C1q, which circulates in plasma as part of a calcium-dependent pentamolecular complex, together with two molecules of $\mathrm{C} 1 \mathrm{r}$ and two molecules of $\mathrm{C} 1 \mathrm{~s}$, then binds to the constant region of the antigen-bound antibody (IgM or $\operatorname{IgG})^{3}$. The binding of $\operatorname{IgM}$ to an antigen then causes a conformational change, within the pentameric $\mathrm{C} 1$ protein thereby exposing C1q-binding sites that otherwise are hidden ${ }^{3}$. Although, IgG, like IgM has also C1q-binding sites, it requires specific binding density to achieve IgM-like affinity with $\mathrm{C}_{1} \mathrm{q}^{3}$. The binding of $\mathrm{Clq}$ in turn induces a conformational change in the pentamolecular complex, leading to activation of $\mathrm{C} 1 \mathrm{r}$ followed by activation of $\mathrm{C} 1 \mathrm{~s}^{4}$. $\mathrm{C} 1 \mathrm{~s}$ subsequently cleaves $\mathrm{C} 4$ into $\mathrm{C} 4 \mathrm{a}$, which diffuses away, and $\mathrm{C} 4 \mathrm{~b}$, which binds via a thioester bond to the cell surface ${ }^{3}$. Complement $\mathrm{C} 2$ recognizes the cleaved C4b complement and binds to it, allowing further cleavage by $\mathrm{C} 1 \mathrm{~s}$ to produce $\mathrm{C} 2 \mathrm{a}$ and $\mathrm{C} 2 \mathrm{~b}$. The $\mathrm{C} 2 \mathrm{~b}$ then remains bound to $\mathrm{C} 4 \mathrm{~b}$ and causes the assembly of an enzymatically active multi-protein complex: the $\mathrm{C} 3$ convertase $(\mathrm{C} 4 \mathrm{bC} 2 \mathrm{~b})$. Cleavage of $\mathrm{C} 3$ by $\mathrm{C} 3$ convertase in turn generates two fragments: C3a and $\mathrm{C} 3 \mathrm{~b} . \mathrm{C} 3 \mathrm{a}$ is an anaphylatoxin, which can trigger inflammation, cell migration, and activation. The $\mathrm{C} 3 \mathrm{~b}$ fragment on the other hand binds to $\mathrm{C} 4 \mathrm{bC} 2 \mathrm{~b}$ to form the $\mathrm{C} 5$ convertase $\mathrm{e}^{3}$. In a manner similar to $\mathrm{C} 3, \mathrm{C} 5$ then gets cleaved to produce the anaphylatoxin $\mathrm{C} 5 \mathrm{a}$, and $\mathrm{C} 5 \mathrm{~b}$. Like $\mathrm{C} 3 \mathrm{a}, \mathrm{C} 5 \mathrm{a}$ promotes inflammation by increasing vasodilation and vascular permeability and releases pro-inflammatory mediators through the activation of granulocytes and macrophages ${ }^{5}$. C5b subsequently interacts

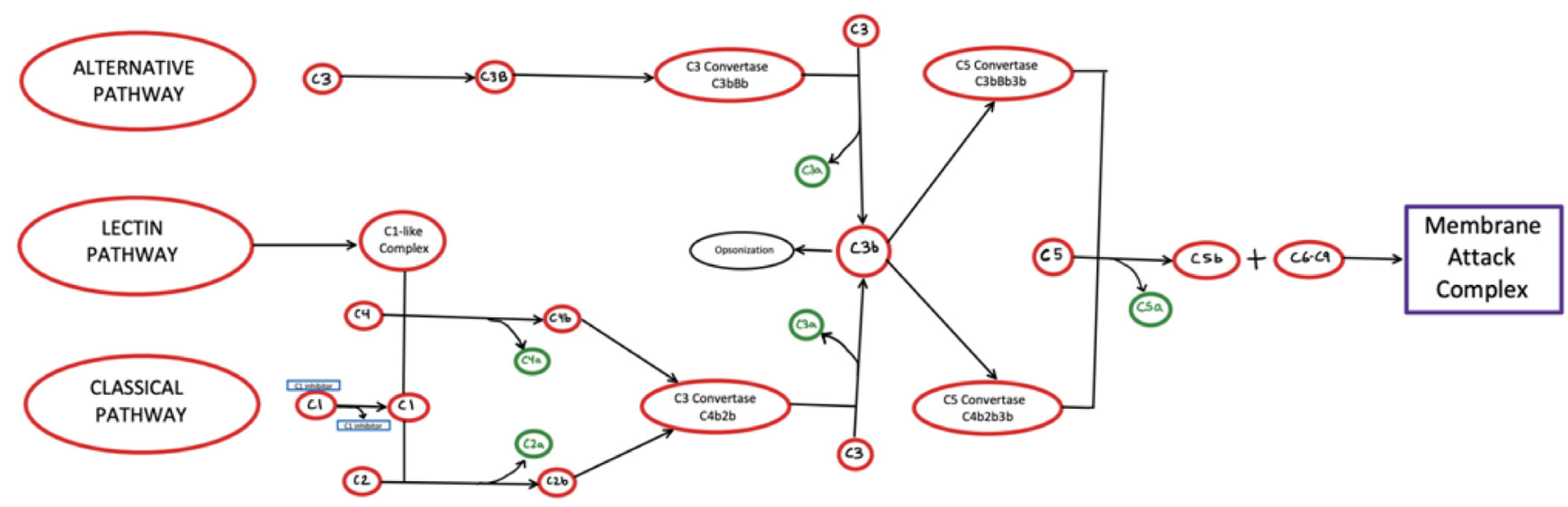

Figure 1. A model of the complement system, including the different pathways. The classical pathway is activated via recognition of $\mathrm{C} 1 \mathrm{q}$ to antigen-bound antibody constant regions. The alternative pathway is activated via a "tickover" process in which low-level hydrolysis of complement C3 initiates C3 convergence. Lastly, the lectin pathway is activated by either mannose-binding lectin or ficolins. As seen above, all three pathways converge on C3, ultimately allowing for the development of the common terminal pathway, producing membrane attack complex, which is then responsible for producing an osmotic imbalance in target cells, eventually leading to cell lysis. 
sequentially with $\mathrm{C} 6, \mathrm{C} 7, \mathrm{C} 8$ and $\mathrm{C} 9$ to form the $\mathrm{C} 5 \mathrm{~b}-9$ complex or MAC, an effector protein that directly forms transmembrane channels on the surface of pathogen cell membranes and is responsible for pore formation and eventual cell lysis ${ }^{3}$.

The alternative complement pathway is activated by bacterial and viral structures, specifically bacterial endotoxin, which is a lipopolysaccharide on the outer membrane of Gram-negative bacteria. The activation of the alternative complement pathway occurs via a process termed "tickover" of $\mathrm{C} 3$, a spontaneous low-level hydrolysis of $\mathrm{C} 3$ to form $\mathrm{C} 3\left(\mathrm{H}_{2} \mathrm{O}\right) . \mathrm{C} 3\left(\mathrm{H}_{2} \mathrm{O}\right)$ then acquires the ability to bind to factor $\mathrm{B}$, which induces a conformational change in factor $\mathrm{B}$, making it susceptible for cleavage by factor $\mathrm{D}$, thus generating $\mathrm{Ba}$ and $\mathrm{Bb}$ fragments ${ }^{6}$. The $\mathrm{Bb}$ fragment remains bound to the initial complex and self-regulates the cleavage of numerous $\mathrm{C} 3$ molecules to produce $\mathrm{C} 3 \mathrm{~b}$. $\mathrm{C} 3 \mathrm{~b}$ proceeds to interact with factor $\mathrm{B}$, resulting in the generation of the initial alternative pathway $\mathrm{C} 3$ convertase. Another mechanism of activation of the alternative complement pathway is through properdin. Properdin is a gamma globulin protein, which binds to $\mathrm{C} 3 \mathrm{~b}$ and subsequently activates factor $\mathrm{B}$ and factor $\mathrm{D}$, resulting in the formation of $\mathrm{C} 3 \mathrm{bBb}, \mathrm{a} \mathrm{C} 3$ convertase $^{5}$. The rest of the function of the alternative complement pathway is similar to that of the classical pathway in that $\mathrm{C} 3$ convertase promotes the development of the C5 convertase, which then produces the MAC.

The lectin pathway of the complement system of humans is activated by mannose-binding lectin (MBL) or one of the three types of ficolins (L-ficolin, M-ficolin, and H-ficolin), recognizing and binding to patterns of sugars or acetyl groups on the surfaces of microorganisms ${ }^{7-10}$. MBL-associated serine protease (MASP) dimers form complexes with either MBL or ficolin that upon binding to pathogens cause a conformational change in MASP ${ }^{11,12}$. The MASP, often MASP-1 or MASP-2, cleaves and activates another MASP in the same complex ${ }^{12}$. The activated MASP then cleaves complement proteins $\mathrm{C} 2$ and $\mathrm{C} 4$, which respectively release the fragments $\mathrm{C} 2 \mathrm{a}$ and $\mathrm{C} 4 \mathrm{~b}^{13}$. These two fragments associate with each other and form the lectin pathway $\mathrm{C} 3$ convertase, $\mathrm{C} 4 \mathrm{~b} 2 \mathrm{a}^{13}$. Much like in the classical and alternative pathways, $\mathrm{C} 4 \mathrm{~b} 2 \mathrm{a}$ cleaves $\mathrm{C} 3$ into $\mathrm{C} 3 \mathrm{a}$, which is released to initiate a local inflammatory response, and $\mathrm{C} 3 \mathrm{~b}$ fragments, which covalently bind to pathogen surfaces and interact with $\mathrm{C} 4 \mathrm{~b} 2 \mathrm{a}$ to make the C5 convertase ${ }^{14}$. Additionally, pathogens bound to $\mathrm{C} 3 \mathrm{~b}$ can activate the alternative pathway and are engulfed by phagocytes expressing receptors for $\mathrm{C} 3 \mathrm{~b}^{13}$. C5b, formed from the cleavage of $\mathrm{C} 5$, then initiates the formation of MAC in a manner similar to the classical pathway ${ }^{13}$.

Because of its potential to lyse and destroy normal bystander cells, each step of the activation is tightly regulated by specific enzymes. Therefore, the complement system not only constitutes a powerful arm of innate immunity but also serves as a bridge between innate and adaptive immunity. Discovered more than a century ago as a system that "complements" the function of antibodies in the process of phagocytic elimination of pathogenic microorganisms from the site of infection, it is now regarded as a system involved in a myriad of immunological functions that can be both protective and destructive to the organism. It is not surprising, therefore, that tumor cells have developed many methods of not only protecting themselves from its destructive power but employing complement proteins to also enhance their own survival and growth. The significance of complement in health and disease is further demonstrated by the fact that deficiency in complement components such as $\mathrm{C} 1 \mathrm{q}, \mathrm{C} 2$, and $\mathrm{C} 4$, though uncommon, is associated with a diverse array of pathological disorders, including autoimmune diseases and susceptibility to infections. Deficiency in C3, for example, is very rare as it can lead to severe infections and other inflammatory diseases. Similarly, knocking out MBL in mice was shown to lead to an increased susceptibility to infection, abnormal inflammatory responses and coagulation, and protection from ischemia-reperfusion injuries ${ }^{10}$. Additionally, asparaginase, used in the treatment of acute lymphoblastic leukemia, has been shown to inhibit the lectin pathway of the complement system by reducing its effect on levels of mannan-bound MBL/MASP-1 and MBL/MASP-2 complexes ${ }^{15}$. Moreover, knocking out ficolin, which has a role similar to that of MBL in the lectin pathway, has also been shown to increase susceptibility to infection in mice ${ }^{10}$.

\section{The role of the complement system in tumor progression}

Tumor cells have been shown not only to synthesize selected complement proteins but also to express and display receptors for complement proteins ${ }^{16}$. For example, plasma concentrations of C3 and C5a were shown to increase in mice with metastatic breast cancer, and blockade of the $\mathrm{C} 5 \mathrm{a}$ receptor (C5aR) reduced lung metastases ${ }^{16}$. C5aR has also been shown to inhibit recruitment and function of $\mathrm{CD}^{+}$and $\mathrm{CD}^{+}$cells and to suppresses $\mathrm{T}$-cell responses in organs where tumors have metastasized in these mice ${ }^{16}$. Although silencing the C3 and C5 in mice with ovarian cancer reduces tumor growth, it has been proposed that this reduction is independent of $\mathrm{T}$ cells ${ }^{17}$ and is likely due to the action of another complement protein. Levels of $\mathrm{C} 4 \mathrm{~d}$, a fragment of complement protein $\mathrm{C} 4 \mathrm{~b}$ generated in the classical pathway, are elevated in patients with lung cancer ${ }^{18}$ and patients with oral and oropharyngeal squamous cell carcinoma ${ }^{19}$.

Complement proteins also interact with tumor-associated macrophages (TAMs) and tumor-associated neutrophils, both of which contribute to tumor progression. TAMs have been shown to non-specifically promote growth and metastasis of malignant metastatic tumors in vitro, directly interact with cancer cells, promote angiogenesis, and suppress adaptive immunity ${ }^{20,21}$. Although TAMs are present in the tumor microenvironment (TME) and are associated with tumor progression, their role is unclear $^{22}$. C1q can induce polarization of macrophages, which express increased levels of programmed death-ligand 1 (PD-L1) and PD-L2 as well as suppressed surface CD40 and suppressed proliferation of inflammatory $\mathrm{T}$ cells after polarization ${ }^{23}$. Other complement fragments capable of inducing macrophage polarization include $\mathrm{C} 5 \mathrm{a}$ and $\mathrm{C} 5 \mathrm{aR}$, the latter of which is expressed on TAMs and plays a role in the regulation of the M2 phenotype of $\mathrm{TAMs}^{24}$. C5a also stimulates the release of leukotriene B4 from epithelial and endothelial cells, which 
helps facilitate neutrophil recruitment ${ }^{25}$. Furthermore, inappropriate activation of the complement system and deposition of complement proteins have been observed as common characteristics of various tumors ${ }^{26}$. This activation in turn is postulated to contribute to tumor cell proliferation, migration, invasion, and epithelial-mesenchymal transition. In particular, the complement system is responsible for the introduction of potent anaphylatoxins that have been linked to various effects on the TME-promoting pathways directed toward immune evasion ${ }^{27}$.

\section{Complement and the adaptive immune response}

Immune invasion is a hallmark of cancer and allows cancer cells to survive and proliferate explosively under disguise. The complement system plays a large part in the ability of cancer to circumvent the immune system. Therefore, it is important to examine the complement activity in the TME. The production of antibodies, lysis of pathogens, B-lymphocyte activation, and opsonization are some of the many critical functions of the immune system which are facilitated by and dependent on the complement system. Many complement proteins such as MBL, ficolins, and most importantly C1q play pivotal roles in pathogen recognition ${ }^{28}$. The intertwined nature of the complement and immune system makes the former the perfect target for cancerous cells to take advantage of in their quest for immune evasion.

A recent study on $\mathrm{C} 1 \mathrm{q}$ and its receptors showed that the proliferation of the breast cancer cell line $\mathrm{SkBr} 3$ is inhibited by addition of either exogenous $\mathrm{C} 1 \mathrm{q}$ or its globular head domains, presumably by blockade of surface $\mathrm{gClqR}$-dependent pro-proliferative signaling ${ }^{29}$. Since actively dividing tumor cells are known to overexpress as well as release $\mathrm{gClqR}$ into the tumor cell microenvironment, it is postulated that the secreted $\mathrm{gC} 1 \mathrm{qR}$ serves either as an autocrine signal for cancer cell proliferation or as a molecular shield protecting the tumor cell from $\mathrm{C} 1 \mathrm{q}$-induced tumor cell destruction ${ }^{29}$. Indeed, exogenous $\mathrm{C} 1 \mathrm{q}$ has been shown to activate p38 and caspase 3 to induce apoptosis via autophagy. Furthermore, ADAM28 (a disintegrin and metalloproteinase 28) is overexpressed in certain carcinomas and actually reduces $\mathrm{C} 1 \mathrm{q}$-induced cytotoxicity ${ }^{30}$.

$\mathrm{Clq}$ is a versatile regulatory complement protein for cancer in that it can promote proliferation when bound to $\mathrm{gClqR}$ and cause cell apoptosis depending on where the interaction is taking place in the TME. Human $\mathrm{T}$ cells of the adaptive immune system are known to express $\mathrm{Clq}$ and its receptors and can induce anti-proliferative, apoptotic signals involving the proliferation/activation of $\mathrm{T}$ cells. Specifically, $\mathrm{C} 1 \mathrm{q}$ in the TME can suppress $\mathrm{CD}^{+} \mathrm{T}$ cells by binding to the $\mathrm{gC} 1 \mathrm{qR}$ in a manner similar to that of the PDL-1 and PD-1 axis ${ }^{31,32}$. As a modified self, a cancer cell perforce expresses proteins that induce antibody production. These "autoantibodies" in turn have the potential to bind to the tumor cell antigen forming a suitable target for $\mathrm{C} 1 \mathrm{q}$ binding and complement activation resulting in MAC-mediated destruction. This phenomenon, however, never happens as the tumor cell microenvironment is rich in molecules that collectively serve as a molecular shield preventing this from happening. Included among these molecules are various complement proteins (such as $\mathrm{C} 3, \mathrm{C} 3 \mathrm{a} / \mathrm{C} 3 \mathrm{aR}, \mathrm{C} 5 \mathrm{a} / \mathrm{C} 5 \mathrm{aR}$, and $\mathrm{C} 1 \mathrm{q}$ ) and membrane-bound complement regulatory proteins (mCRPs), both of which have increased expression in many malignant tumors and cancer cell lines ${ }^{33}$. There is also evidence that overexpression of mCRPs in cancer cells may protect them from complement-mediated attack by MAC and eventual cell lysis ${ }^{26,34}$. One of these molecules is secreted $\mathrm{gClqR}$, which (as mentioned earlier) can bind to $\mathrm{Clq}$ and activate the classical pathway in the pericellular rather than on the tumor cell surface. In addition, soluble $\mathrm{gC} 1 \mathrm{qR}$ can bind and activate the kinin system, thereby generating activation fragments such as bradykinin - a potent vasoactive peptide which can induce vascular permeability and thus enhance cancer cell metastasis. Thus, by simultaneous activation of the complement system and the kinin system, activation fragments that collectively contribute to tumor cell survival, proliferation, and metastasis are generated $^{29}$.

\section{Complement and immunosuppression}

Among the many hallmarks of cancer, immune evasion is one that contributes to its deadly and elusive properties. Mechanisms of cancer allow for the perversion of proto-oncogenes and the silencing of tumor suppressors that otherwise would allow the body to effectively contain and prevent a tumor growth. Immune evasion and the blindsiding nature of cancer can be effects of "immune editing", in which tumors suppress T-cell function, anti-cancerous secretions and immune system mediators ${ }^{35}$. One of the pivotal components of the TME is the myeloidderived suppressor cell (MDSC), which have been shown to assist in tumor evasion from responses of the immune system, promote tumor resistance to immunotherapy, and sustain tumor survival and progression due to suppression of $\mathrm{T}$ cell-dependent tumor cytotoxicity through mechanisms involving production of nitric oxide and cytokines ${ }^{36}$. Studies have provided evidence for a correlation between the recruitment and activation of MDSCs in tumors with complement activation via $\mathrm{C}^{2} \mathrm{a}^{3}$. Specifically, C5a has been identified as a chemoattractant for a subsect of MDSCs that produce and release reactive oxygen and nitrogen species for efficient immunosuppression ${ }^{3}$. Additionally, C5a has been found to have a profound influence on the functional capability of MDSCs in suppressing $\mathrm{CD}^{+} \mathrm{T}$ cell-mediated anti-tumor responses, as shown by experiments in which isolated MDSCs from C5aR-deficient mice were unable to suppress the proliferation of $\mathrm{T}$ cells ${ }^{25}$. Thus, the recruitment of MDSCs into the tumor site by C5a is critical in generating an immunosuppressive microenvironment through the inhibition of $\mathrm{T}$ cell-mediated anti-tumor responses.

\section{Complement and angiogenesis}

Angiogenesis, the formation of new blood vessels within the tumor mass, is a critical aspect of tumor survival and growth. For tumors to continue growing in size, they require nutrition, oxygen, and waste removal like normal tissues. The only way that cancer cells, deeply lodged in tumor tissue, can receive these critical necessities is through the formation of new blood vessels or angiogenesis. Although angiogenesis is known to occur during wound healing and the reproductive cycle, it is not active at all times. Therefore, tumors hijack and use this 
regulated, ordinary bodily function to continuously grow and expand $^{37}$. The new vascular networks generated during angiogenesis additionally assist the proliferation and metastatic spread of cancer cells. Studies conducted to examine the relationship between complement components and angiogenesis have found both pro-angiogenic and anti-angiogenic roles in neovascularization ${ }^{3}$. Examination of epithelial ovarian cancer in genetically $\mathrm{C} 3$-deficient and C5aR knockout mice demonstrated dysregulated endothelial cells, impairing tumor vascularization as well as altered vascular endothelial growth factor (VEGF) expression ${ }^{38}$. VEGF is a key cytokine for tumor metastasis and its concentration has been found to be directly proportional to malignancy ${ }^{39}$. However, C3-deficient and C5aR-deficient mice were found to have increased pathological retina neovascularization, indicating that the absence of these complement proteins resulted in increased postnatal angiogenesis ${ }^{40}$. This dual function of complement in turn suggests that complement activation may be relevant only in the context of initial tumor formation. Additionally, mice with homozygous C1q deficiency were shown to have defective vessel formation that was restored to normal by locally applying $\mathrm{C} 1 \mathrm{q}^{41}$.

\section{Complement and inflammation}

Several studies have suggested that tumor-promoting inflammation is a considerably pivotal component of the TME and is responsible for the reciprocal promotion of tumor growth. Among the hallmarks of cancer-related inflammation are TAMs, the presence of pro-inflammatory cytokines and chemokines, and the infiltration of white blood cells ${ }^{42}$. As mentioned earlier, C5a is a potent anaphylatoxin, which induces inflammation through its ability to stimulate the release of histamine from mast cells ${ }^{39}$. It has been shown that C5a signaling results in the increased expression of interleukin 6 (IL-6), which is responsible for responding to infections and tissue injuries and whose dysregulated synthesis can have pathological effects on chronic inflammation and autoimmunity ${ }^{43}$. The veracity of this concept was shown in a mouse model of lung carcinogenesis in which blocking $\mathrm{C} 5 \mathrm{aR}$ signaling resulted in the downregulation of IL-6 expression ${ }^{5}$. Clinical studies have demonstrated that increased levels of serum IL-6 have been associated with advanced tumorigenesis in various cancers, including multiple myeloma, non-small cell lung carcinoma, colorectal cancer, renal cell carcinoma, breast cancer, and ovarian cancer ${ }^{5}$. Additionally, local complement activation in the TME contributes to the inhibition of tumor-infiltrating lymphocytes (TILs), which are responsible for $\mathrm{IL}-10$ production ${ }^{44}$. In a murine model of melanoma, it was shown that the ability of CD8+ TILs to secrete IL-10 was inhibited by $\mathrm{C} 3 \mathrm{a}$ and $\mathrm{C} 5 \mathrm{a}^{44}$. Inhibition of IL-10 in the presence of tumorigenic activity in turn results in unregulated inflammation, thereby impeding pathogen clearance and mitigating immunosuppressive functions ${ }^{45}$.

\section{Complement and inhibition of apoptosis}

To combat rampant cell proliferation, tumor suppressor genes in the genome, induce apoptosis in certain cases such as aging cells, abnormally divided cells, and genetically damaged cells. In cancer, however, tumor suppressors are inactivated, which allows cancerous cells to continue proliferating ${ }^{46}$. Two well-studied tumor suppressor genes are $R B$ (retinoblastoma), which is mutated in retinoblastoma, and TP53, which is most commonly mutated in human cancers ${ }^{47}$. Many downstream products of oncogenes can have pro-tumor activities, and the stress from this oncogenic signaling along with DNA damage is a cue for apoptosis to occur. If tumor suppressors such as TP53 are silenced, apoptosis cannot happen. This inactivation, combined with proliferative signaling from oncogenes, is a leading cause of tumorigenesis. Thus, the cell damage-sensing capabilities of TP53 are critical for the prevention of cancer $^{2}$.

Recent studies have suggested that complement activation may promote tumor progression via anti-apoptotic mediators (Figure 2). C5a has been shown to prevent apoptotic caspase 3 activation and DNA fragmentation ${ }^{39}$. Additionally, the binding of $\mathrm{C} 5 \mathrm{a}$ to $\mathrm{C} 5 \mathrm{aR}$ has led to activation of the mitogen-activated protein kinase (MAPK) pathway, which has inhibitory effects on glutamate-induced apoptosis ${ }^{39}$. It was also observed that C3 inhibition resulted in increased basal and cytokine-induced apoptosis in beta cells and that the addition of exogenous C3 prevents this apoptosis ${ }^{48}$. C1q binds to surface blebs on apoptotic keratinocytes and apoptotic vascular endothelial cells via its globular head domains and can initiate uptake of apoptotic cells into macrophages ${ }^{49-51}$. Defects in complement-dependent clearance of apoptotic cells have been associated with increased susceptibility to autoimmunity development ${ }^{52}$. For example, C1q- and C4-deficient mice were shown to have impaired clearance of apoptotic cells, resulting in the development of a lupus-like disease ${ }^{48}$. One study showed that mice with homozygous $\mathrm{C} 1 \mathrm{q}$ deficiency develop glomerulonephritis associated with multiple apoptotic bodies and that the mice that did not develop glomerulonephritis had significantly higher levels of glomerular apoptotic bodies ${ }^{53}$. As previously stated, the role of complement in tumor progression is twofold and is dependent on the specific TME. Therefore, understanding of the complement components in the tumor cell microenvironment and the conditions that promote or enhance tumorigenesis and tumor survival is critical.

\section{C1q and its role as a cancer-promoting factor}

The first component of complement $\mathrm{Clq}$ is unique in that it is predominantly synthesized extrahepatically by macrophages, dendritic cells (DCs), endothelial cells, fibroblasts, and microglial cells. It is a $460-\mathrm{kDa}$ hexameric glycoprotein with six collagen-like regions and six globular heads (Figure 3) 54,55. $^{5}$. Each unit of this hexamer consists of polypeptide chains A $(28 \mathrm{kDa}), \mathrm{B}(25 \mathrm{kDa})$, and $\mathrm{C}(24 \mathrm{kDa})$ that form a collagen-like triple-helical strand between their $\mathrm{N}$ terminal regions and form a globular head from their $\mathrm{C}$ terminal regions ${ }^{56,57}$. Additionally, there are disulfide bonds between chains $\mathrm{A}$ and $\mathrm{B}$ within a strand as well as between the $\mathrm{C}$ chains of two adjacent strands, thus forming a doublet ${ }^{58}$. $\mathrm{C} 1 \mathrm{q}$ is the recognition subunit of the classical pathway complex $\mathrm{C}^{59}$. Recent experimental evidence shows that in addition to playing a role in triggering the classical pathway of complement activation and phagocytosis, C1q plays a significant role in cancer ${ }^{60,61}$. 


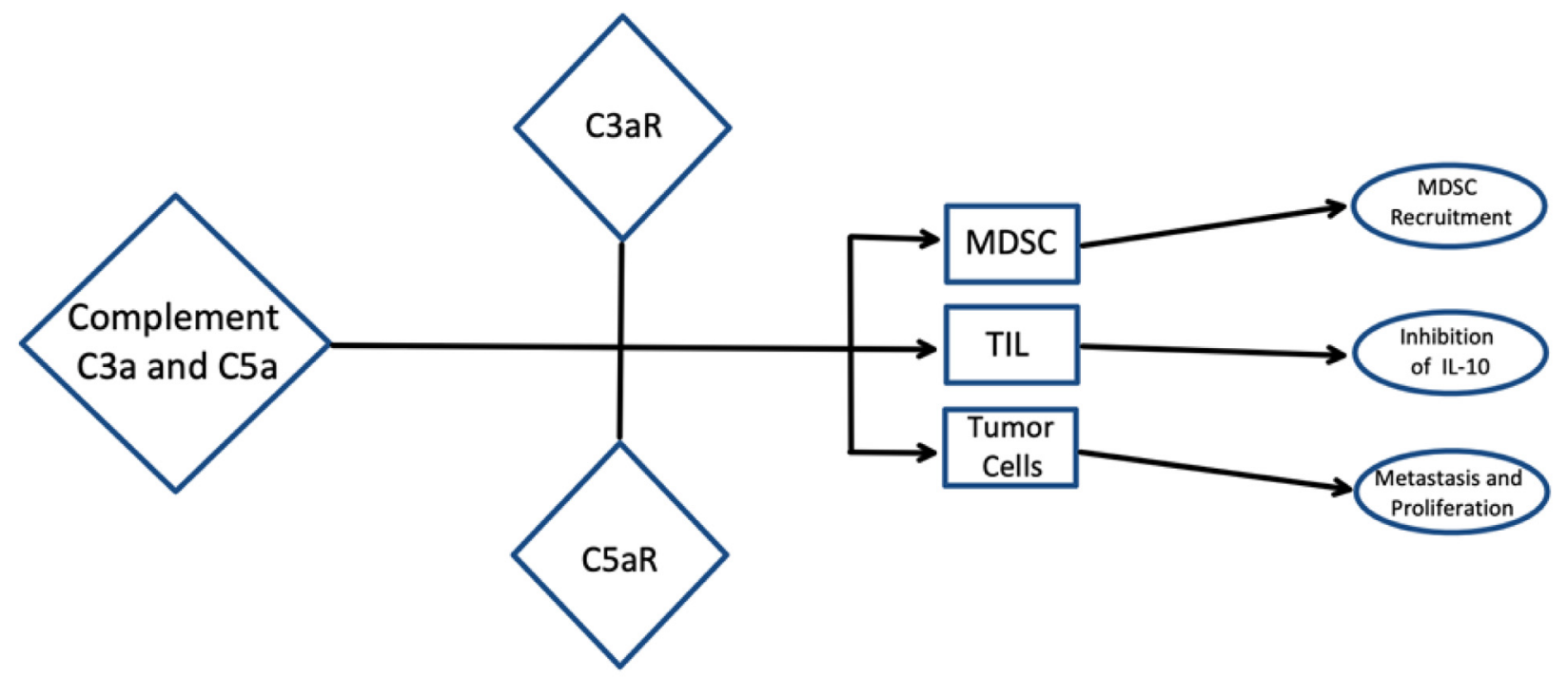

Figure 2. Complement and inhibition of apoptosis. A model displaying the role of complement activation, specifically via complement proteins C3 and C5, in the tumor microenvironment. The complement system promotes the release of C3a and C5a, which are responsible for tumor progression. $\mathrm{C} 5 \mathrm{a}$ is a chemoattractant for certain myeloid cells, including myeloid-derived suppressor cells (MDSCs), into the tumor. MDSCs are responsible for producing and releasing certain oxygen and nitrogen species, resulting in immunosuppression. C5a has also been shown to suppress CD8+ tumor-infiltrating lymphocytes (TILs) which in turn reduces interleukin-10 (IL-10) production, ultimately promoting inflammation and inhibition of pathogen clearance. Complement proteins can also develop an autocrine loop in which cell proliferation and additional metastasis promotion are presented. Thus, C3a and C5a have been shown to mediate complement activation on MDSCs, TILs, and cancer cells.
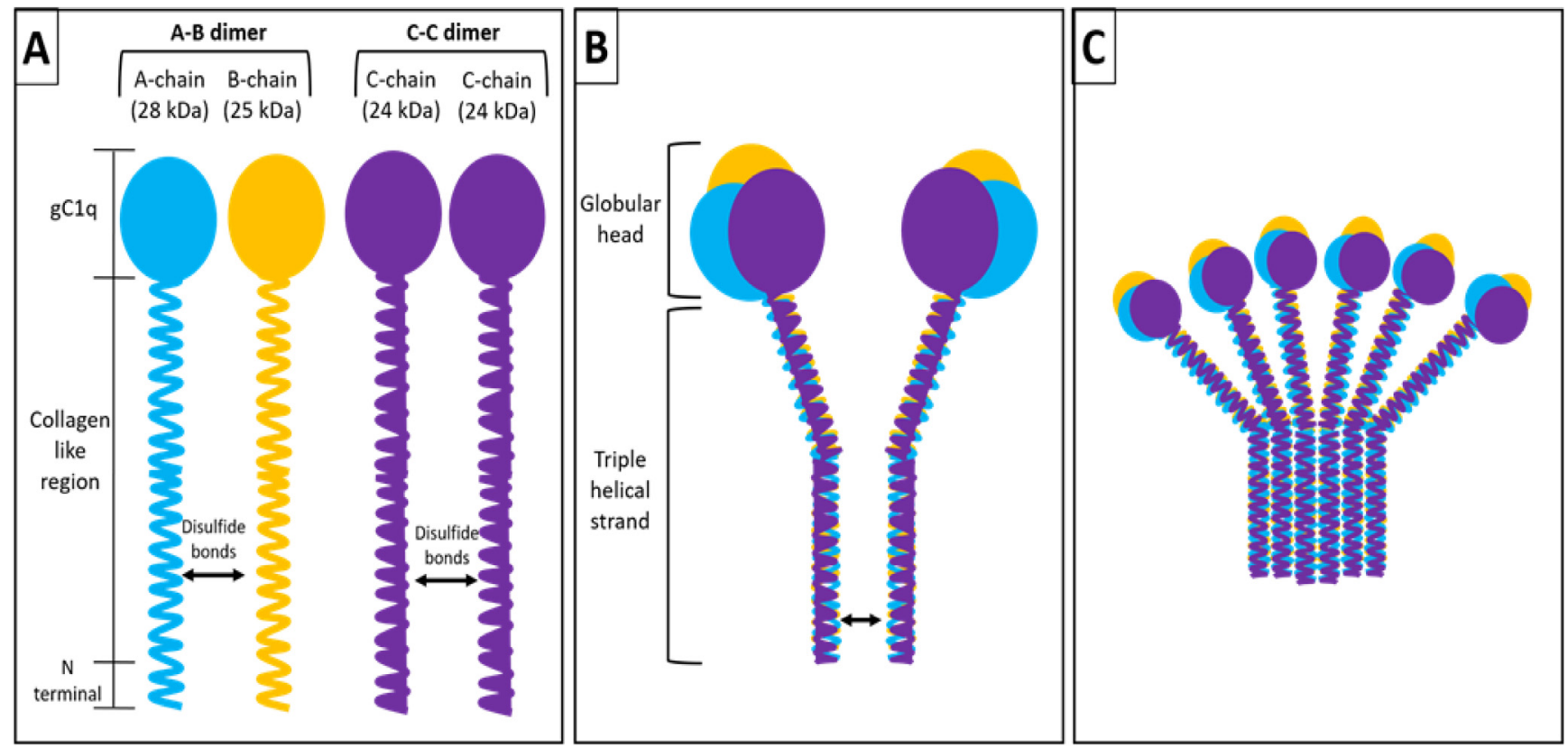

Figure 3. Structure of C1q. The intact C1q molecule ( $460 \mathrm{kDa}$ ) is assembled from 18 similar but distinct individual chains (6A, 6B, and 6C) The chains are organized to form 6 individual strands each of which consists of a single A (28 kDa), B (25 kDa) and C (24 kDa) chains. The three chains are the product of three distinct genes which are highly clustered and aligned 5' to $3^{\prime \prime}$ in the same orientation in the order ACB on a $24 \mathrm{~kb}$ stretch on chromosome 1p. In each strand, the A chain is disulfide linked to the B chain, whereas the C chain is disulfide linked to the $\mathrm{C}$ chain of a neighboring strand to form a doublet. Three doublets are associated by strong non-covalent forces to give the intact $\mathrm{C} 1 \mathrm{q}$ molecule its characteristic hexameric and "bouquet of tulips" like electron microscopic structure62. 
The fact that $\mathrm{C} 1 \mathrm{q}$ induces angiogenesis indicates that it plays a major role in tumor growth ${ }^{41}$. In prostate cancer, for example, C1q has been shown to destabilize cell adhesion by activating the tumor suppressor WOX1, thereby blocking cancer cell proliferation and induction of apoptosis ${ }^{63}$. In a mouse model of melanoma, it was shown that those that were C1q-deficient were found to have reduced tumor mass, prolonged survival, and fewer lung metastases in comparison with wild-type mice ${ }^{64}$. C1q is also expressed in the TME on vascular endothelial cells, spindle-shaped fibroblasts, and monocytoid cells ${ }^{64}$.

Complement $\mathrm{C} 1 \mathrm{q}$ has been shown to mediate various immunoregulatory functions, including enhancement of phagocytosis, regulation of cytokine production in antigen-presenting cells, and enhancement of T-lymphocyte maturation ${ }^{65}$. Recent studies also have shown that C1q can enhance cancer development and proliferation. Indeed, the level of $\mathrm{C} 1 \mathrm{q}$ is increased within the TME of most cancer cells and is also ${ }^{64}$ synthesized within the TME by macrophages and DCs to enhance pro-tumorigenic activity, including angiogenesis ${ }^{66}$. Therefore, the local synthesis of C1q provides strong evidence for the observed C1q-mediated functions that are independent of complement activation.

C1q has been identified in the stroma and vascular endothelium of several human malignant tumors, including colon, lung, breast, pancreatic carcinoma, and melanoma ${ }^{65}$. This abnormal presence indicates that the activation of the classical pathway via $\mathrm{C} 1 \mathrm{q}$ can be related to complement-mediated tumor progression. Bulla et al. showed an increased deposition of $\mathrm{Clq}$ and associated augmentation of vascular density and lung metastases in wild-type mice in comparison with $\mathrm{C} 1 \mathrm{q}$-deficient $\left(\mathrm{Clqa}^{--}\right)$ mice $^{64}$. Additionally, it was observed that the C1q-deficient mice showed stagnant tumor growth and extended survival ${ }^{64}$. These findings support the premise that locally synthesized $\mathrm{C} 1 \mathrm{q}$ is a tumor-promoting factor and enhances many processes that favor tumor progression, including cell adhesion, migration, proliferation angiogenesis, and metastasis ${ }^{66}$.

Agostinis et al. examined the role of $\mathrm{Clq}$ in the microenvironment of malignant pleural mesothelioma (MPM) and identified that $\mathrm{C} 1 \mathrm{q}$ bound to hyaluronic acid (HA) via its globular domain subsequently acquired pro-tumorigenic properties, inducing adhesion, migration, and proliferation of mesothelioma cells ${ }^{67}$. HA has also been identified to promote proliferation and migration of MPM cells via binding to the hyaluronan receptor. However, HA-bound $\mathrm{Clq}$ showed increased adhesion of mesothelioma cells in comparison with independent HA. This finding suggests that $\mathrm{C} 1 \mathrm{q}$ does indeed have a pro-tumorigenic effect on mesothelioma cells, a property that appears to be a factor common to various other tumors. Additionally, HA-bound C1q was shown to promote MPM tumor progression by enhancing mesothelioma cell proliferation and migration in comparison with $\mathrm{HA}$ or $\mathrm{Clq}$ alone.

Other studies have suggested that $\mathrm{C} 1 \mathrm{q}$ has a binary function in relation to cancer, having both pro-tumorigenic and anti-tumorigenic properties. For example, in the MPM environment, C1q was shown to implement a defensive response against apoptosis, thereby enhancing tumorigenesis ${ }^{67}$. However, C1q was also shown to induce apoptosis and mitigate the growth of human prostate DU145 cells ${ }^{63}$. Ultimately, the degree of complement activation has been determined to be dependent on the specific tumor type as well as the degree of inflammation corresponding to tumor proliferation. Certain tumors have been shown to reduce the cellular response to $\mathrm{C} 1 \mathrm{q}$ by decreasing the number of $\mathrm{C} 1 \mathrm{q}$ receptors on the cell surface in an attempt to restrain apoptosis induction ${ }^{66}$. Since there are two types of $\mathrm{C} 1 \mathrm{q}$ receptors, one recognizing its globular heads $(\mathrm{gClqR})$ and the other binding to its collagen tails $(\mathrm{cClqR})$, the orientation of the bound $\mathrm{C} 1 \mathrm{q}$ molecule (that is, heads versus tails) may explain the various $\mathrm{C} 1 \mathrm{q}-$ mediated functions.

\section{C1qRs and their roles in cancer}

The two receptors for $\mathrm{C} 1 \mathrm{q}-\mathrm{cC} 1 \mathrm{qR} / \mathrm{CR}$ and $\mathrm{gClqR}$ - are highly upregulated on many types of tumors and may have different functions in tumor cells ${ }^{20}$. Blockade of these receptors with monoclonal antibodies (mAbs) has been shown to inhibit tumor growth, suggesting that these receptors play a role in tumor progression $^{68}$.

$\mathrm{cC} 1 \mathrm{qR} / \mathrm{CR}$ is a $60-\mathrm{kDa}$ membrane protein that binds predominantly to the collagen region of $\mathrm{Clq}$ and is identical to calreticulin $(\mathrm{CR})^{69,70}$. Its structure reveals three beta sheets and three hydrophobic clusters ${ }^{71}$. In addition to binding to $\mathrm{C} 1 \mathrm{q}$, $\mathrm{cC} 1 \mathrm{qR}$ binds to mannan-binding protein, conglutinin, and lung surfactant protein, all of which have collagen domains ${ }^{72}$. $\mathrm{cC} 1 \mathrm{qR} / \mathrm{CR}$ has been shown to mark malignant cells for destruction by macrophages ${ }^{20}$. Phagocytosis of apoptotic cells by human monocyte-derived macrophages has been shown to be effectively inhibited by anti-cClqR antibodies ${ }^{51}$. Indeed, cC1qR/CR-induced phagocytosis of tumor cells was shown to be suppressed by blocking or knocking down cC1qR/CR as well as by the increased expression of CD47 on malignant cells $^{73,74}$. cC1qR has also been shown to bind to the collagen tails of $\mathrm{C} 1 \mathrm{q}$ and MBL attached to apoptotic cells ${ }^{51}$.

Another receptor for $\mathrm{C} 1 \mathrm{q}$ is $\mathrm{gC} 1 \mathrm{qR}$ - also referred to as $\mathrm{p} 33$, p32, and HA-binding protein (HABP1) — which binds to the globular heads of $\mathrm{C}_{1 q^{75}}$. Its crystal structure reveals that it is a homotrimer with two differentially charged faces: a highly charged face called the solution face (or S-face) and a less charged one called the membrane face (or M-face). Each subunit of the trimer is composed of a seven-strand antiparallel beta sheet and three alpha helices ${ }^{75}$. The S-face of the trimer contains the C1q-binding site ${ }^{76} \cdot \mathrm{gClqR}$ is a ubiquitously distributed multi-functional and multi-compartmental molecule, and is unique in that it contains both an ITAM (immunoreceptor tyrosine-based activation motif) and an ITIM (immunoreceptor tyrosine-based inhibition motif) ${ }^{77}$. It is abundantly and ubiquitously expressed on the surface of a wide range of cell types including endothelial cells, platelets, and $\mathrm{T}$ cells as well as in the mitochondrial matrix. Experimental evidence accumulated to date shows that $\mathrm{gClqR}$ can interact with various molecules in the tumor cell environment, including proteins of the kinin system such as factor XII and high-molecular-weight kininogen 
(HK), thereby triggering activation of the kinin-kallikrein system (KKS) resulting in the generation of bradykinin-one of the most potent vasoactive peptides known $^{78}$.

The binding of $\mathrm{gC} 1 \mathrm{qR}$ to inflammatory molecules indicates its role in tumor progression due to the large influence of inflammatory cells on the $\mathrm{TME}^{79}$. It has been shown that the addition of $\mathrm{mAb}$ that blocks the C1q-binding site of $\mathrm{gC} 1 \mathrm{qR}$ inhibits cell proliferation ${ }^{80}$. Moreover, proliferating tumor cells secrete $\mathrm{gC} 1 \mathrm{qR}$ into the pericellular milieu as a defense mechanism to prevent the tumor cell from C1q-mediated cellular damage ${ }^{20}$. Because surface-expressed as well as secreted $\mathrm{gClqR}$ is crucial for tumor cell survival, it has become a potential target for the development of anti-tumor therapy ${ }^{78}$. Although (by virtue of its ubiquitous expression) an off-target effect using antibody or small molecule-based therapy is indeed of concern, it is possible to target only the antigenic site responsible for the anti-tumor effect without inhibiting other sites that are critical for other biologic functions.

\section{The $\mathrm{C} 1 \mathrm{q}-\mathrm{gC1qR}$ axis as a potential novel checkpoint inhibitor}

The gC1q-binding site on $\mathrm{gClqR}$ is covered by residues 76 to 93 located on the $\mathrm{gClqR} S$-face ${ }^{73,81}$ and this interaction has been shown to activate the classical pathway of complement. More pertinently, the addition of $\mathrm{C} 1 \mathrm{q}$ to mitogen-induced proliferating $\mathrm{T}$ cells has been shown to inhibit cell proliferation ${ }^{82,83}$. Similarly, the addition of exogenous C1q to breast cancer cells in culture was shown to have an anti-proliferative effect whereas the addition of recombinant $\mathrm{gC1qR}$ was pro-proliferative ${ }^{16}$. Since $\mathrm{C} 1 \mathrm{q}, \mathrm{cC} 1 \mathrm{qR}$, and $\mathrm{gClqR}$ are expressed by breast cancer cells and have roles in cancer cell proliferation, the $\mathrm{C} 1 \mathrm{q}-\mathrm{gC} 1 \mathrm{qR}$ axis and the $\mathrm{C} 1 \mathrm{q}-\mathrm{cClqR}$ axis represent potential new targets for the development of anti-cancer therapy ${ }^{16}$.

The $\mathrm{C} 1 \mathrm{q}-\mathrm{gC} 1 \mathrm{qR}$ interaction in the TME appears to mimic that of the PD-1/PD-L1 interaction with the cancer cell surface-expressed C1q serving the role of PD-L1 and the immune cell-expressed $\mathrm{gC} 1 \mathrm{qR}$ serving the role of PD-1, thereby attenuating the T-cell signals directed at attacking the tumor cells ${ }^{19}$. PD-1 is expressed on many immune cells, such as natural killer cells, monocytes, activated T cells, and B cells and even weakly on immature $\mathrm{T}$ cells and $\mathrm{B}$ cells ${ }^{84,85}$. Its ligand, PD-L1, is expressed by a variety of cells, including lymphocytes, monocytes, and lung cells, and is upregulated in tumor cells ${ }^{86,87}$. The binding of PD-1 to PD-L1 activates intracellular signaling pathways and inhibits immune cell activation ${ }^{84}$. The PD-1/PD/L1 axis can also suppress T-cell proliferation by inhibiting the Ras/MEK/ERK pathway ${ }^{88}$. The $\mathrm{C} 1 \mathrm{q}$ that is expressed on tumor cells is anchored via a membrane-binding domain located on the A-chain, thereby exposing the six globular heads outwardly to bind to as many as six antigens simultaneously. This configuration therefore would be extremely efficient in binding to multiple $\mathrm{gClqR}$ molecules expressed on the $\mathrm{T}$ cells or other immune cells in the TME, thereby inhibiting their anti-tumor functions and enhancing uninhibited tumor cell growth.

\section{gC1qR as a marker of cell proliferation}

The complement system contains many components that are involved in the TME and one of its key factors is the multi-functional $\mathrm{gC} 1 \mathrm{qR}$. In addition to being found in various compartments of the cell, $\mathrm{gC} 1 \mathrm{qR}$ has been shown to be an important modulator of extracellular and intracellular ligands. In oncogenesis and the development of cancer, gC1qR is of great interest as it appears to be upregulated in various adenocarcinomas ${ }^{75}$.

Evidence accumulated to date suggests that $\mathrm{gC} 1 \mathrm{qR}$ potentially serves as a marker of cell proliferation as it is overexpressed in most epithelial tumors. The study, by Dembitzer et al., highlighted the changes in $\mathrm{gC} 1 \mathrm{qR}$ expression among various types of tumor tissues ${ }^{78}$. Employing UltraVision LP Detection System (Thermo Fisher Scientific Inc., Waltham, MA, USA) and the mAb 60.11 to $\mathrm{gC1qR}$, Dembitzer et al. showed expression of $\mathrm{gClqR}$ in both mesenchymal and epithelial tissue that was malignant, normal, inflammatory, or dysplastic. Staining techniques and light microscopy yielded results showing that mesenchymal tumors had weaker $\mathrm{gClqR}$ expression than epithelial tumors. Epithelial tumors, normal cells that were proliferating, and benign inflammatory lesions were noted to have the strongest $\mathrm{gClqR}$ expression ${ }^{78}$. The results of this study are highly suggestive that $\mathrm{gClqR}$ plays a role in the proliferation of certain tumorigenic cells and its elevated levels may indicate malignant tissue growth.

It is known that membrane-bound $\mathrm{gClqR}$ can bind to the globular heads of $\mathrm{C} 1 \mathrm{q}$ and thereby trigger classical pathway complement activation. The interaction of $\mathrm{C} 1 \mathrm{q}$ with membrane-bound $\mathrm{gC} 1 \mathrm{qR}$ is therefore vital for innate immune response to infection of cells ${ }^{89-91}$. Recent experiments have provided evidence that soluble $\mathrm{gClqR}$ that is secreted into the TME serves as a proliferative autocrine signal ${ }^{16}$. The study used the $\mathrm{SkBr} 3 \mathrm{Her}^{+}$ breast cancer cell line that expresses $\mathrm{cC} 1 \mathrm{qR}, \mathrm{gC} 1 \mathrm{qR}$, and C1q. When the cells were cultured with anti-Clq that binds to membrane-bound C1q, cell growth was completely inhibited, suggesting the profound effect of membrane-bound $\mathrm{C} 1 \mathrm{q}$ on cell proliferation. A similar effect was achieved when the cells were cultured with purified $\mathrm{C} 1 \mathrm{q}$ or its globular heads that are known to bind to $\mathrm{gClqRs}$. When recombinant $\mathrm{gC} 1 \mathrm{qR}$ was added to the cells, however, the effect was different. There was, instead a great increase in cell growth ${ }^{16}$.

Employing techniques in immunohistochemistry and immunocapture sandwich ELISA (enzyme-linked immunosorbent assay), the tissue expression of $\mathrm{gC} 1 \mathrm{qR}$ and the blood serum of healthy controls and pancreatic cancer patients were examined. The results of the study confirmed that $\mathrm{gC} 1 \mathrm{qR}$ is overexpressed in pancreatic adenocarcinoma when compared with healthy tissue. The serum levels of soluble $\mathrm{gC} 1 \mathrm{qR}$ in healthy controls were noted to be $0.15 \pm 0.10 \mathrm{ng} / \mathrm{mL}$. In patients with pancreatic cancer, the levels were $0.29 \pm 0.22 \mathrm{ng} / \mathrm{mL}$ and a majority of these metastatic patients displayed an increase in $\mathrm{gC} 1 \mathrm{qR}$ serum levels as their condition worsened ${ }^{92}$. This indicates the significance of soluble $\mathrm{gClqR}$ as a marker and possibly even an 
initiator of robust cellular proliferation. Another study explored the overexpression of $\mathrm{gC} 1 \mathrm{qR}$ in MPM of 265 patients $^{90}$. The data indicated that $\mathrm{gClqR}$ overexpression was found in all types of MPM, which were proliferative compared with normal tissue, and that expression levels could be tied to the overall survival of a patient. Therefore, measuring gClqR levels is a possible prognostic tool in the future ${ }^{90}$.

It has also been observed that sites of inflammation that are characterized by the expression of $\mathrm{gCl} \mathrm{qR}$, both in the soluble form and on cell surfaces, can trigger complement activation. Since $\mathrm{gClqR}$ potentially activates both the classical pathway of complement and the KKS, it can contribute to the inflammatory processes via the generation of vasoactive peptides from both the complement system and the $\mathrm{KKS}^{93}$. Similar to the autocatalytic activation characterized in the complement system, components of the KKS (factor XII, prekallikrein, and high-molecular-weight $\mathrm{HK}$ ) undergo proteolytic enzyme cascade sequences which allows the generation of bradykinin ${ }^{93}$. Initial binding to a negatively charged cell surface causes the conversion of factor XII to XIIa, which in turn leads to the conversion of prekallikrein to kallikrein (Figure 4), and the latter is responsible for the digestion of $\mathrm{HK}$ to generate bradykinin ${ }^{93}$. Since HK binds to surface-expressed or soluble gC1qR with high affinity, the tumor cell surface as well as the TME, which is rich in $\mathrm{gClqR}$, provide a suitable milieu for the generation of bradykinin ${ }^{94}$. The kinin receptors such as $\mathrm{B} 2 \mathrm{~K}$, which is constitutively expressed on a wide range of cells, and the $\mathrm{B} 1 \mathrm{~K}$, which is inducible by $\mathrm{IL}-1 \beta$ and soluble $\mathrm{gC} 1 \mathrm{qR}$ (Figure 4), have been identified as promising targets for cancer therapy for a multitude of reasons: (a) production of kinins is a common characteristic in cancer since they are often used as autocrine factors to promote tumorigenesis, (b) kinins possess pro-angiogenic properties, (c) abnormally high concentrations of these receptors are expressed by tumor cells, and (d) components of the TME, including macrophages and DCs, are activated following activation of kinin receptors ${ }^{95}$.

Although the major function of bradykinin is to induce the swelling seen in angioedema, recent studies have suggested that bradykinin is also involved in tumor metastasis and angiogenesis. Furthermore, bradykinin has been shown to directly stimulate the growth of tumors as well as induce neovascularization of tumors via release of $\mathrm{VGEFs}^{96}$. In addition, bradykinin has been shown to release matrix metalloproteases which facilitate tumor cell migration and invasion ${ }^{96}$. Therefore, if the KKS involvement is to be mitigated, then blockade of $\mathrm{gClqR}$ may be a suitable option for drug design (Figure 5).

\section{Therapeutic potential of complement in the tumor microenvironment}

The $\mathrm{SkBr} 3$ breast cancer studies have shown that secreted soluble $\mathrm{gClqR}$ can protect the tumor cell from $\mathrm{C} 1 \mathrm{q}$ and complement-mediated destruction. Although future investigation has to be carried out to see whether this holds true for other cancer types, it is known that many cancer cells express these proteins in the TME. Therefore, blockade of the secreted $\mathrm{gC} 1 \mathrm{qR}$ in the TME potentially weakens tumor cell defenses and allows immune cells to dispose of the cancer cells ${ }^{16}$. Other complement proteins are also highly involved in the TME. Studies have found that serum levels of $\mathrm{C} 3 \mathrm{a}$ and $\mathrm{C} 5 \mathrm{a}$ are elevated in certain cancers and can be used as biomarkers for tumorigenic progression ${ }^{97,98}$. $\mathrm{C} 3 \mathrm{a}$ and $\mathrm{C} 4 \mathrm{a}$ can be predictive elements of a patient's response to chemotherapy as there is a higher amount of these complement

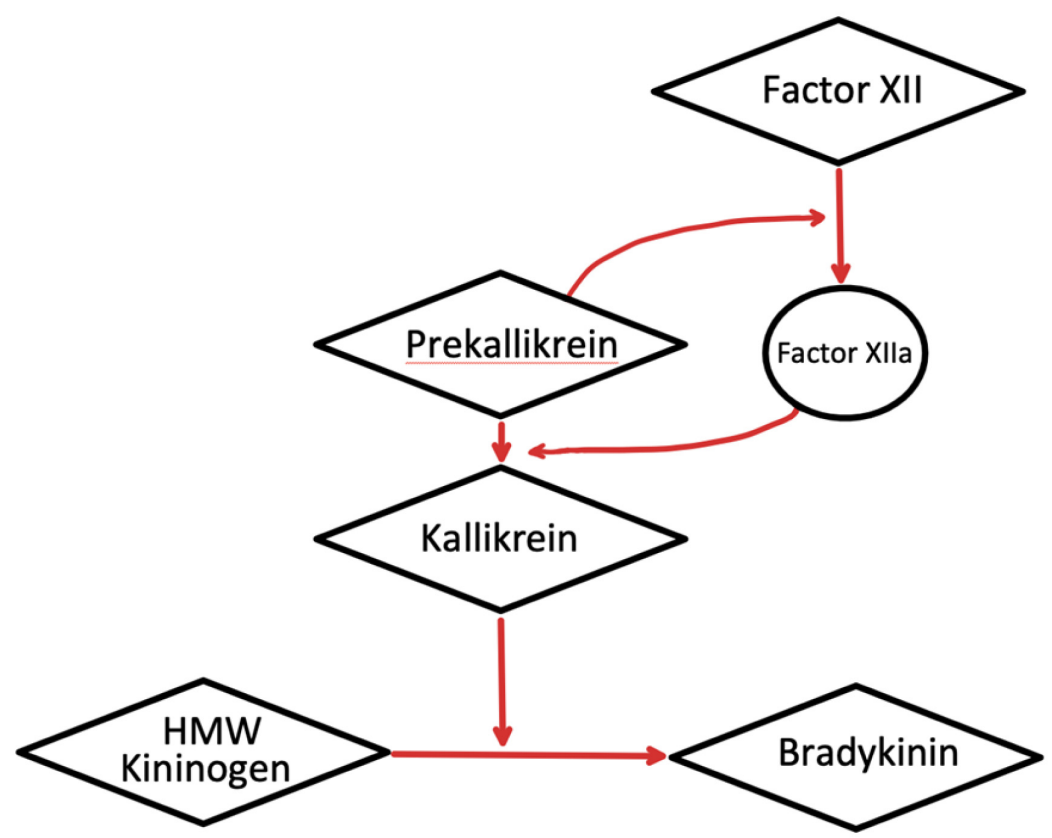

Figure 4. A schematic representation demonstrating the kallikrein-kinin system activation. HMW, high-molecular-weight. 


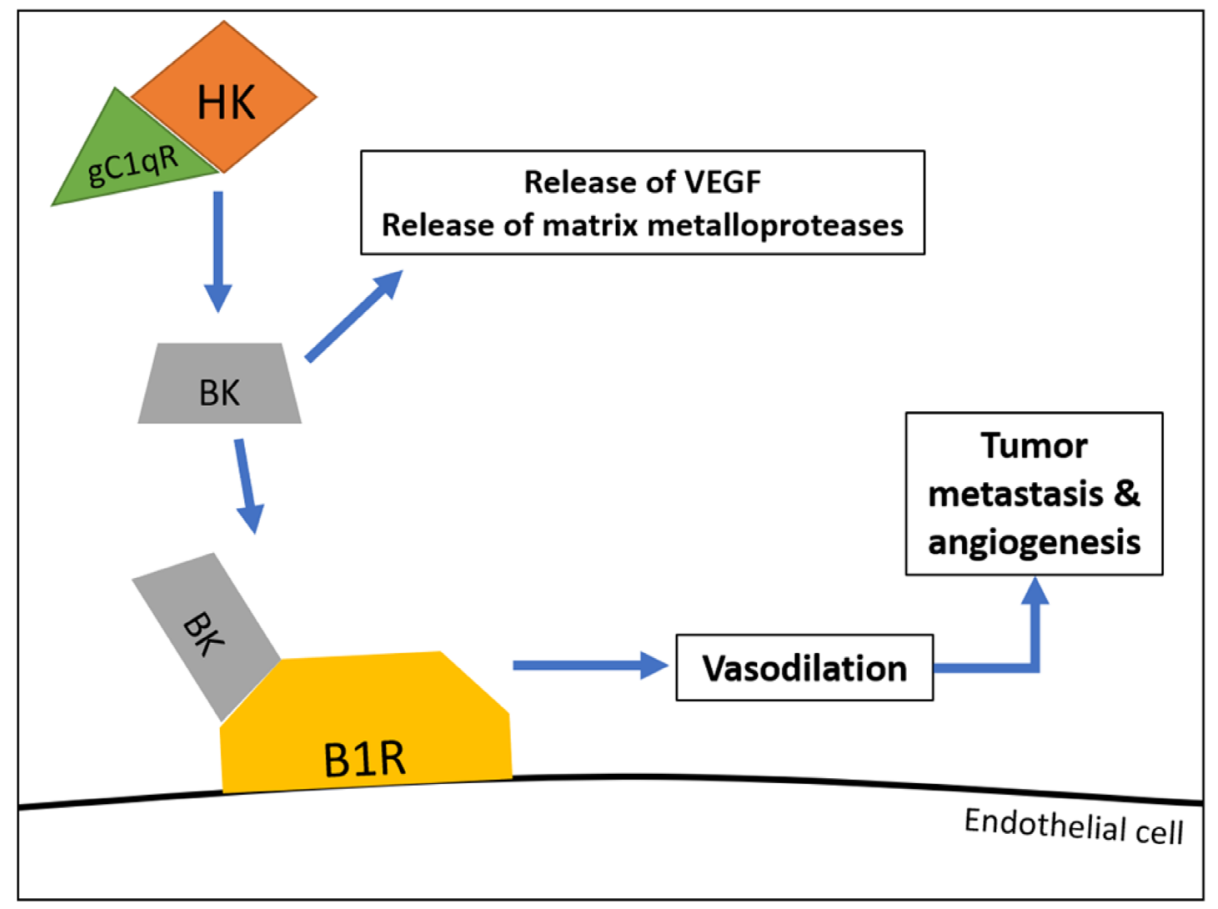

Figure 5. Hypothetical model demonstrating the role of $\mathrm{gC1qR}$ in bradykinin generation and subsequent vascular permeability. In this partial model, high-affinity binding of high-molecular-weight kininogen (HK) to gC1qR leads to bradykinin (BK) generation. Bradykinin hereafter binds to bradykinin receptor 1 (B1R) receptors found on endothelial cells, inducing vasodilation, which leads to tumor metastasis and angiogenesis. VEGF, vascular endothelial growth factor.

components in poor responders ${ }^{99}$. It has also been shown that $\mathrm{C} 3 \mathrm{aR}$ or $\mathrm{C} 5 \mathrm{aR}$ blockade has the ability to disrupt $\mathrm{DC}$ and T-cell activation and alter the effects of radiotherapy in certain carcinomas. Thus, there is growing evidence that the components of the complement system can all be good prognostic factors and even potential targets for therapy ${ }^{26}$.

The dual role of complement in cancer allows for potential therapeutic targets in anti-tumor studies. As discussed by Kourtzelis and Rafail ${ }^{100}$, a probable opportunity would be to introduce bi-specific mAbs that have the capacity to recognize two different epitopes concurrently, thereby allowing for selective neutralization of complement regulation. This would inherently permit a safe pathway for specific antibody-mediated clearance of tumor cells without causing unnecessary harm to other cells. Given that many complement proteins are essential for the proper function of the host immune response, creating therapeutic targets specifically for such components could create undesirable effects that inflict more harm through novel passages for tumor progression. However, selective neutralization of these complement components may allow for effective anti-tumor therapies, as shown by blockade of $\mathrm{C} 3 \mathrm{aR}$ and $\mathrm{C} 5 \mathrm{aR}^{26}$. In fact, an anti-C5aR1 antibody, IPH5401, in combination with durvalumab, is in an ongoing phase I trial for advanced solid tumors $^{101}$. Durvalumab, a drug that blocks interaction of PD-1 and PD-L1, was included on the basis of preclinical data suggesting that the use of an anti-PD-L1 therapy with IPH5401 would reduce tumor growth, delay tumor progression, and improve overall efficacy ${ }^{101}$.

Indeed, the relevance of complement in carcinogenesis is becoming clear. Therefore, it will not be long before targeted therapeutic modalities are designed to block the deleterious effect of a specific complement protein.

\section{Conclusions}

The complement system undoubtedly plays an important role in the TME. The $\mathrm{gC} 1 \mathrm{qR}$ and $\mathrm{C} 1 \mathrm{q}$ axis are vital elements that are potential therapeutic targets. As a modified self, a tumor cell is capable of expressing modified self-antigens that induce antibody production. These antibodies in turn can bind to the antigen target on the tumor cell, making it susceptible to recognition by $\mathrm{C} 1 \mathrm{q}$ and destruction by complement ${ }^{16}$. Therefore, disarming of the $\mathrm{gClqR}$ "blockade" should weaken tumor cell defenses and allow immune cells to dispose of the cancerous cells appropriately.

Various components of the complement pathway have been shown to play a role in complement activation and tumor progression. In particular, $\mathrm{C} 1 \mathrm{q}$ has been shown in increased quantities within the TME without the subsequent presence of other vital complement proteins, indicating the relevance of 
$\mathrm{C} 1 \mathrm{q}$ and its involvement within the tumor progression independent of complement activation. Several studies have suggested that in the presence of $\mathrm{Clq}$, tumor progression was more rampant compared with absence of $\mathrm{C} 1 \mathrm{q}$, which displayed stagnant tumor growth and extended survival for cancer. Indeed, this shows that more research is needed to understand the exact role that $\mathrm{C} 1 \mathrm{q}$ plays within the TME. In addition, it has been shown that $\mathrm{C} 1 \mathrm{q}$ induces either pro-tumorigenic properties or anti-tumorigenic properties depending on the orientation of the C1q molecule upon binding and the specific tumor cell that it binds to. This orientation in turn depends on whether it binds to $\mathrm{gC} 1 \mathrm{qR}$ or $\mathrm{cC} 1 \mathrm{qR}$ on the cell surface. The multiplicity of roles that complement activation plays in the TME is increasing. It plays a role in immunosuppression through the recruitment and activation of MDSCs and is involved in neovascularization and angiogenesis, one of the notable hallmarks of cancer in which tumor cells have the ability to proliferate and metastasize through manipulative usage of nutrients and oxygen present within the environment. Complement activation in the TME also suggests that tumor-promoting inflammation is a critical component in tumor progression via the dysregulation of ILs, specific glycoproteins responsible for the recruitment of leukocytes that supervise the host immune response. Furthermore, activation of complement in the TME has been shown to prevent the activation of apoptotic components leading to inhibition of host programmed cell death and evasion of malignant cells. Therefore, the role of complement in cancer progression and survival is an area of research that has been steadily progressing albeit at a snail's pace. Studies that ensure appropriate activation and functioning of complement proteins as well as the design of inhibitory components that restrain deleterious effects of complement are thus sorely missing.

\section{Abbreviations}

$\mathrm{C} 5 \mathrm{aR}, \mathrm{C} 5 \mathrm{a}$ receptor; cC1q, the collagen domain of $\mathrm{C} 1 \mathrm{q}$; $\mathrm{cC} 1 \mathrm{qR}$, receptor for $\mathrm{cClq}$; $\mathrm{CR}$, calreticulin (another name for $\mathrm{cClqR}$ ); $\mathrm{DC}$, dendritic cell; $\mathrm{gC} 1 \mathrm{q}$, globular head of $\mathrm{C} 1 \mathrm{q}$; $\mathrm{gClqR}$, receptor for $\mathrm{gClq}$; ghA, ghB, and ghC, globular heads of the $\mathrm{A}, \mathrm{B}$, and $\mathrm{C}$ chains of $\mathrm{Clq}$; $\mathrm{HA}$, hyaluronic acid; HK, kininogen; IL, interleukin; KKS, kinin-kallikrein system; mAb, monoclonal antibody; MAC, membrane attack complex; MASP, mannose-binding lectin-associated serine protease; MBL, mannose-binding lectin; mCRP, membrane-bound complement regulatory protein; MDSC, myeloid-derived suppressor cell; MPM, malignant pleural mesothelioma; PD-L, programmed death-ligand; S-face, solution face; TAM, tumor-associated macrophage; TIL, tumor-infiltrating lymphocyte; TME, tumor microenvironment; VEGF, vascular endothelial growth factor
1. Roy PS, Saikia BJ: Cancer and cure: A critical analysis. Indian J Cancer. 2016; 53(3): 441-2.

PubMed Abstract

2. Hanahan D, Weinberg RA: Hallmarks of cancer: The next generation. Cell. 2011; 144(5): 646-74.

PubMed Abstract | Publisher Full Text | Faculty Opinions Recommendation

3. Pio R, Corrales L, Lambris JD: The role of complement in tumor growth. Adv Exp Med Biol. 2014; 772: 229-62.

PubMed Abstract | Publisher Full Text | Free Full Text

4. Kojouharova M, Reid K, Gadjeva M: New insights into the molecular mechanisms of classical complement activation. Mol Immunol. 2010; 47(13): 2154-60.

PubMed Abstract | Publisher Full Text

5. Kleczko EK, Kwak JW, Schenk EL, et al.: Targeting the Complement Pathway as a Therapeutic Strategy in Lung Cancer. Front Immunol. 2019; 10 954.

PubMed Abstract | Publisher Full Text | Free Full Text |

Faculty Opinions Recommendation

6. Thurman JM, Holers VM: The central role of the alternative complement pathway in human disease. $J$ Immunol. 2006; 176(3): 1305-10. PubMed Abstract | Publisher Full Text

7. Weis WI, Taylor ME, Drickamer K: The C-type lectin superfamily in the immune system. Immunol Rev. 1998; 163: 19-34. PubMed Abstract | Publisher Full Text

8. Garlatti V, Belloy N, Martin L, et al:: Structural insights into the innate immune recognition specificities of $L$ - and $\mathrm{H}$-ficolins. EMBO J. 2007; 26(2): 623-33. PubMed Abstract | Publisher Full Text | Free Full Text

9. Genster N, Takahashi M, Sekine $\mathrm{H}$, et al: Lessons learned from mice deficient in lectin complement pathway molecules. Mol Immunol. 2014; 61(2): 59-68. PubMed Abstract | Publisher Full Text

10. Chen $\mathrm{CB}$, Wallis R: Stoichiometry of complexes between mannose-binding protein and its associated serine proteases. Defining functional units for complement activation. J Biol Chem. 2001; 276(28): 25894-902. PubMed Abstract | Publisher Full Text

11. Murphy K: Innate Immunity: The First Lines of Defense. In Immunobiology (8th ed.). Garland Science, 2012.
12. Evans-Osses I, de Messias-Reason I, Ramirez MI: The emerging role of complement lectin pathway in trypanosomatids: Molecular bases in activation, genetic deficiencies, susceptibility to infection, and complement systembased therapeutics. ScientificWorldJournal. 2013; 2013: 675898 . based therapeutics. ScientificWorldJournal. 2013; 2013:
PubMed Abstract | Publisher Full Text | Free Full Text

13. Wallis R, Mitchell DA, Schmid R, et al:: Paths reunited: Initiation of the classical and lectin pathways of complement activation. Immunobiology. 2010; 215(1): and lectir. PubMed Abstract | Publisher Full Text | Free Full Text Keizer MP, Aarts C, Kamp AM, et al:: Asparaginase inhibits the lectin pathway of complement activation. Mol Immunol. 2018; 93: 189-92. PubMed Abstract | Publisher Full Text | Faculty Opinions Recommendation

15. Peerschke EIB, Ghebrehiwet $B:$ :C1qR/CR and gC1qR/p33: Observations in cancer. Mol Immunol. 2014; 61(2): 100-9. PubMed Abstract | Publisher Full Text

16. Vadrevu SK, Chintala NK, Sharma SK, et al: Complement c5a receptor facilitates cancer metastasis by altering T-cell responses in the metastatic niche. Cancer Res. 2014; 74(13): 3454-65. PubMed Abstract | Publisher Full Text

17. Cho MS, Vasquez HG, Rupaimoole R, et al:: Autocrine effects of tumor-derived complement. Cell Rep. 2014; 6(6): 1085-95. PubMed Abstract | Publisher Full Text | Free Full Text

18. Ajona D, Pajares MJ, Corrales L, et al:: Investigation of complement activation product $\mathbf{c} 4 \mathrm{~d}$ as a diagnostic and prognostic biomarker for lung cancer. $J$ Natl Cancer Inst. 2013; 105(18): 1385-93.

PubMed Abstract | Publisher Full Text | Free Full Text

19. Ajona D, Pajares MJ, Chiara MD, et al:: Complement activation product C4d in oral and oropharyngeal squamous cell carcinoma. Oral Dis. 2015; 21(7): 899-904.

PubMed Abstract | Publisher Full Text

20. Mantovani A: Effects on in vitro tumor growth of murine macrophages isolated from sarcoma lines differing in immunogenicity and metastasizing capacity. Int J Cancer. 1978; 22(6): 741-6. PubMed Abstract | Publisher Full Text

21. Bonavita E, Galdiero MR, Jaillon S, et al.: Phagocytes as Corrupted Policemen in Cancer-Related Inflammation. Adv Cancer Res. 2015; 128: 141-71. PubMed Abstract | Publisher Full Text 
22. Powell DR, Huttenlocher A: Neutrophils in the Tumor Microenvironment. Trends Immunol. 2016; 37(1): 41-52. PubMed Abstract | Publisher Full Text | Free Full Text | Faculty Opinions Recommendation

23. Clarke EV, Weist BM, Walsh CM, et al.: Complement protein C1q bound to apoptotic cells suppresses human macrophage and dendritic cell-mediate Th17 and Th1 T cell subset proliferation. J Leukoc Biol. 2015; 97(1): 147-60. PubMed Abstract | Publisher Full Text | Free Full Text

24. Piao C, Zhang WM, Li TT, et al:: Complement 5a stimulates macrophage polarization and contributes to tumor metastases of colon cancer. Exp Cell Res. 2018; 366(2): 127-38.

PubMed Abstract | Publisher Full Text | Faculty Opinions Recommendation

25. Allendorf DJ, Yan J, Ross GD, et al:: C5a-mediated leukotriene $\mathbf{B}$-amplified neutrophil chemotaxis is essential in tumor immunotherapy facilitated by antitumor monoclonal antibody and beta-glucan. J Immunol. 2005; 174(11): 7050-6. PubMed Abstract | Publisher Full Text

26. Zhang R, Liu Q, Li T, et al.: Role of the complement system in the tumor microenvironment. Cancer Cell Int. 2019; 19: 300. PubMed Abstract | Publisher Full Text | Free Full Text | Faculty Opinions Recommendation

27. Markiewski MM, DeAngelis RA, Benencia F, et al.: Modulation of the antitumor immune response by complement. Nat Immunol. 2008; 9(11): 1225-35.

PubMed Abstract | Publisher Full Text | Free Full Text |

Faculty Opinions Recommendation

28. Barbosa AS, Isaac L: Complement Immune Evasion by Spirochetes. Cur Top Microbiol Immunol. 2018; 415: 215-38.

PubMed Abstract | Publisher Full Text | Faculty Opinions Recommendation

29. Kandov E, Kaur A, Kishore U, et al.: C1q and C1q receptors (gC1qR and cC1qR) as potential novel targets for therapy against breast cancer. Immunology. 2018; 19: $59-76$ Reference Source

30. Miyamae $\mathrm{Y}$, Mochizuki S, Shimoda M, et al.: ADAM28 is expressed by epithelial cells in human normal tissues and protects from C1q-induced cell death. FEBS J. 2016; 283(9): 1574-94.

PubMed Abstract | Publisher Full Text

31. Chen A, Gaddipati S, Hong $Y$, et al:: Human T cells express specific binding sites for C1q. Role in T cell activation and proliferation. $J$ Immunol. 1994; 153(4): 1430-40. PubMed Abstract

32. Cai J, Wang D, Zhang G, et al.: The Role Of PD-1/PD-L1 Axis In Treg Development And Function: Implications For Cancer Immunotherapy. Onco Targets Ther. 2019; 12: 8437-45.

PubMed Abstract | Publisher Full Text | Free Full Text | Faculty Opinions Recommendation

33. Afshar-Kharghan V: The role of the complement system in cancer. J Clin Invest 2017; 127(3): 780-9.

PubMed Abstract | Publisher Full Text | Free Full Text

34. Cui W, Zhao Y, Shan C, et al:: HBXIP upregulates CD46, CD55 and CD59 through ERK1/2/NF-KB signaling to protect breast cancer cells from complement attack. FEBS Lett. 2012; 586(6): 766-71. PubMed Abstract | Publisher Full Text

35. Vinay DS, Ryan EP, Pawelec G, et al:: Immune evasion in cancer: Mechanistic basis and therapeutic strategies. Semin Cancer Biol. 2015; 35 Suppl: S185S198.

PubMed Abstract | Publisher Full Text

36. Gabrilovich DI: Myeloid-Derived Suppressor Cells. Cancer Immunol Res. 2017; 5(1): 3-8.

PubMed Abstract | Publisher Full Text | Free Full Text

37. Hanahan D, Folkman J: Patterns and Emerging Mechanisms of the Angiogenic Switch during Tumorigenesis. Cell. 1996; 86(3): 353-64. PubMed Abstract | Publisher Full Text

38. Nunez-Cruz S, Gimotty PA, Guerra MW, et al.: Genetic and pharmacologic inhibition of complement impairs endothelial cell function and ablates ovarian cancer neovascularization. Neoplasia. 2012; 14(11): 994-1004. PubMed Abstract | Publisher Full Text | Free Full Text

39. Darling VR, Hauke RJ, Tarantolo S, et al:: Immunological effects and therapeutic role of C5a in cancer. Expert Rev Clin Immunol. 2015; 11(2): 255-63. PubMed Abstract | Publisher Full Text | Free Full Text

40. Langer HF, Chung KJ, Orlova VV, et al.: Complement-mediated inhibition of neovascularization reveals a point of convergence between innate immunity and angiogenesis. Blood. 2010; 116(22): 4395-403. PubMed Abstract | Publisher Full Text | Free Full Text

41. Bossi $\mathrm{F}$, Tripodo $\mathrm{C}$, Rizzi L, et al.: $\mathrm{C} 1 \mathrm{q}$ as a unique player in angiogenesis with therapeutic implication in wound healing. Proc Natl Acad Sci U S A. 2014; 111(11): 4209-14.

PubMed Abstract | Publisher Full Text | Free Full Text

42. Colotta F, Allavena P, Sica A, et al.: Cancer-related inflammation, the seventh hallmark of cancer: Links to genetic instability. Carcinogenesis. 2009; 30(7): 1073-81.

PubMed Abstract | Publisher Full Text

43. Tanaka T, Narazaki M, Kishimoto T: IL-6 in inflammation, immunity, and disease. Cold Spring Harb Perspect Biol. 2014; 6(10): a016295. PubMed Abstract | Publisher Full Text | Free Full Text | Faculty Opinions Recommendation

44. Wang Y, Sun SN, Liu Q, et al.: Autocrine Complement Inhibits IL10-Dependent T-cell-Mediated Antitumor Immunity to Promote Tumor Progression. Cancer Discov. 2016; 6(9): 1022-35.

PubMed Abstract | Publisher Full Text | Free Full Text

45. Couper KN, Blount DG, Riley EM: IL-10: The master regulator of immunity to infection. J Immunol. 2008; 180(9): 5771-7.

PubMed Abstract | Publisher Full Text

46. Burkhart DL, Sage J: Cellular mechanisms of tumour suppression by the retinoblastoma gene. Nat Rev Cancer. 2008; 8(9): 671-82.

PubMed Abstract | Publisher Full Text | Free Full Text

47. Sherr CJ, McCormick F: The RB and $\mathbf{p} 53$ pathways in cancer. Cancer Cell. 2002; 2(2): 103-12.

PubMed Abstract | Publisher Full Text

48. Dos Santos RS, Marroqui L, Grieco FA, et al:: Protective Role of Complement C3 Against Cytokine-Mediated $\beta$-Cell Apoptosis. Endocrinology. 2017; 158(8): 2503-21.

PubMed Abstract | Publisher Full Text | Free Full Text

49. Korb LC, Ahearn JM: C1q binds directly and specifically to surface blebs of apoptotic human keratinocytes: Complement deficiency and systemic lupus erythematosus revisited. J Immunol. 1997; 158(10): 4525-8. PubMed Abstract

50. Navratil JS, Watkins SC, Wisnieski JJ, et al.: The globular heads of C1q specifically recognize surface blebs of apoptotic vascular endothelial cells. $J$ Immunol. 2001; 166(5): 3231-9. PubMed Abstract | Publisher Full Text

51. Ogden CA, deCathelineau A, Hoffmann PR, et al:: C1q and mannose binding lectin engagement of cell surface calreticulin and CD91 initiates macropinocytosis and uptake of apoptotic cells. J Exp Med. 2001; 194(6): 781-95.

PubMed Abstract | Publisher Full Text | Free Full Text |

Faculty Opinions Recommendation

52. Botto M: Links between complement deficiency and apoptosis. Arthritis Res 2001; 3(4): 207-10.

PubMed Abstract | Publisher Full Text | Free Full Text

53. Botto M, Dell'Agnola C, Bygrave AE, et al.: Homozygous C1q deficiency causes glomerulonephritis associated with multiple apoptotic bodies. Nat Genet. 1998; 19(1): 56-9.

PubMed Abstract | Publisher Full Text

54. Ghebrehiwet B, Hosszu KK, Valentino A, et al:: The C1q family of proteins: Insights into the emerging non-traditional functions. Front Immunol. 2012; 3: 52.

PubMed Abstract | Publisher Full Text | Free Full Text

55. Kishore U, Ghai R, Greenhough TJ, et al:: Structural and functional anatomy of the globular domain of complement protein C1q. Immunol Lett. 2004; 95(2): 113-28.

PubMed Abstract | Publisher Full Text | Free Full Text

56. Sellar GC, Blake DJ, Reid KB: Characterization and organization of the genes encoding the A-, B- and C-chains of human complement subcomponent C1q The complete derived amino acid sequence of human C1q. Biochem J. 1991; 274(( Pt 2)(Pt 2)): 481-90.

PubMed Abstract | Publisher Full Text | Free Full Text

57. Reid KB: Chemistry and molecular genetics of C1q. Behring Inst Mitt. 1989; (84): 8-19.

PubMed Abstract

58. Brodsky-Doyle B, Leonard KR, Reid KB: Circular-dichroism and electronmicroscopy studies of human subcomponent $\mathrm{C} 1 \mathrm{q}$ before and after limited proteolysis by pepsin. Biochem J. 1976; 159(2): 279-86.

PubMed Abstract | Publisher Full Text | Free Full Text

59. Lepow IH, Naff GB, Todd EW, et al:: Chromatographic resolution of the first component of human complement into three activities. J Exp Med. 1963; 117(6): 983-1008

PubMed Abstract | Publisher Full Text | Free Full Text

60. Bossi F, Rizzi L, Bulla R, et al.: C1q induces in vivo angiogenesis and promotes wound healing. Mol Immunol. 2011; 48(14): 1676-7. Publisher Full Text

61. Bobak DA, Gaither TA, Frank MM, et al.: Modulation of FcR function by complement: Subcomponent C1q enhances the phagocytosis of IgGopsonized targets by human monocytes and culture-derived macrophages. $J$ Immunol. 1987; 138(4): 1150-6. PubMed Abstract

62. Knobel HR, Villiger W, Isliker $\mathrm{H}$ : Chemical analysis and electron microscopy studies of human C1q prepared by different methods. Eur J Immunol. 1975; 5(1): $78-82$. PubMed Abstract | Publisher Full Text 
63. Hong $\mathrm{Q}$, Sze $\mathrm{Cl}$, Lin $\mathrm{SR}$, et al:: Complement C1q activates tumor suppressor WWOX to induce apoptosis in prostate cancer cells. PLOS One. 2009; 4(6): e5755.

PubMed Abstract | Publisher Full Text | Free Full Text

64. Bulla R, Tripodo C, Rami D, et al:: C1q acts in the tumour microenvironment as a cancer-promoting factor independently of complement activation. Nat Commun. 2016; 7: 10346

PubMed Abstract | Publisher Full Text | Free Full Text

65. Thielens NM, Tedesco F, Bohlson SS, et al.: C1q: A fresh look upon an old molecule. Mol Immunol. 2017; 89: 73-83. PubMed Abstract | Publisher Full Text | Free Full Text

66. Mangogna A, Belmonte B, Agostinis C, et al.: Prognostic Implications of the Complement Protein C1q in Gliomas. Front Immunol. 2019; 10: 2366. PubMed Abstract | Publisher Full Text | Free Full Text | Faculty Opinions Recommendation

67. Agostinis C, Vidergar R, Belmonte B, et al: Complement Protein C1q Binds to Hyaluronic Acid in the Malignant Pleural Mesothelioma Microenvironment and Promotes Tumor Growth. Front Immunol. 2017; 8: 1559. PubMed Abstract | Publisher Full Text | Free Full Text

68. Tosato G, Yao L, Pike SE: Calreticulin and Tumor Suppression. Calreticulin Molecular Biology Intelligence Unit. 2003; 162-179. Publisher Full Text

69. Ghebrehiwet B, Silvestri L, McDevitt C, et al:: Identification of the Raji cell membrane-derived C1q inhibitor as a receptor for human C1q. Purification and immunochemical characterization. J Exp Med. 1984; 160(5): 1375-89. PubMed Abstract | Publisher Full Text | Free Full Text

70. Ghebrehiwet B, Hamburger M: Purification and partial characterization of a C1q inhibitor from the membranes of human peripheral blood lymphocytes. J Immunol. 1982; 129(1): 157-62.

PubMed Abstract

71. Ellgaard L, Riek R, Herrmann T, et al:: Calreticulin P-domain. Proc Natl Acad Sci U S A. 2001; 98(6). Publisher Full Text

72. Malhotra R, Thiel S, Reid KB, et al:: Human leukocyte C1q receptor binds other soluble proteins with collagen domains. J Exp Med. 1990; 172(3): 955-9. PubMed Abstract | Publisher Full Text | Free Full Text

73. Chao MP, Jaiswal S, Weissman-Tsukamoto R, et al:: Calreticulin is the dominant pro-phagocytic signal on multiple human cancers and is counterbalanced by CD47. Sci Transl Med. 2010; 2(63): 63ra94. PubMed Abstract | Publisher Full Text | Free Full Text

74. Obeid M, Tesniere A, Ghiringhelli F, et al:: Calreticulin exposure dictates the immunogenicity of cancer cell death. Nat Med. 2007; 13(1): 54-61. PubMed Abstract | Publisher Full Text | Faculty Opinions Recommendation

75. Jiang J, Zhang Y, Krainer AR, et al:: Crystal structure of human p32, a doughnutshaped acidic mitochondrial matrix protein. Proc Natl Acad Sci U S A. 1999; 96(7): 3572-7.

PubMed Abstract | Publisher Full Text | Free Full Text

76. Ghebrehiwet B, Jesty J, Peerschke EIB: gC1q-R/p33: Structure-function predictions from the crystal structure. Immunobiology. 2002; 205(4-5): 421-32. PubMed Abstract | Publisher Full Text

77. Ghebrehiwet B, Peerschke El: Structure and Function of gC1q-R: A Multiligand Binding Cellular Protein. Immunobiology. 1998; 199(2): 225-38. PubMed Abstract | Publisher Full Text

78. Dembitzer FR, Kinoshita $\mathrm{Y}$, Burstein D, et al:: gC1qR expression in normal and pathologic human tissues: Differential expression in tissues of epithelial and mesenchymal origin. J Histochem Cytochem. 2012; 60(6): 467-74. PubMed Abstract | Publisher Full Text | Free Full Text

79. Coussens LM, Werb Z: Inflammation and cancer. Nature. 2002; 420(6917): 860-7. PubMed Abstract | Publisher Full Text | Free Full Text

80. Ghebrehiwet B, Geisbrecht BV, Xu X, et al.: The C1q Receptors: Focus on gC1qR/p33 (C1qBP, p32, HABP-1)1. Semin Immunol. 2019; 45: 101338 PubMed Abstract | Publisher Full Text

81. Ghebrehiwet B, Lim BL, Peerschke El, et al:: Isolation, cDNA cloning, and overexpression of a 33-kD cell surface glycoprotein that binds to the globular "heads" of C1q. J Exp Med. 1994; 179(6): 1809-21. PubMled Abstract | Publisher Full Text | Free Full Text

82. Peerschke EIB, Yin W, Grigg SE, et al:: Blood platelets activate the classical pathway of human complement. J Thromb Haemost. 2006; 4(9): 2035-42. PubMed Abstract | Publisher Full Text

83. Ghebrehiwet B, Peerschke El: Role of C1q and C1q receptors in the pathogenesis of systemic lupus erythematosus. Curr Dir Autoimmun. 2004; 7: 87-97.

PubMed Abstract | Publisher Full Text

84. Jiang X, Wang J, Deng X, et al:: Role of the tumor microenvironment in PD-L1/PD-1-mediated tumor immune escape. Mol Cancer. 2019; 18(1): 10. PubMed Abstract | Publisher Full Text | Free Full Text Faculty Opinions Recommendation

85. Nishimura $\mathrm{H}$, Agata $\mathrm{Y}$, Kawasaki $\mathrm{A}$, et al.: Developmentally regulated expression of the PD-1 protein on the surface of double-negative (CD4-CD8-) thymocytes. Int Immunol. 1996; 8(5): 773-80.

PubMed Abstract | Publisher Full Text

86. Keir ME, Butte MJ, Freeman GJ: PD-1 and its ligands in tolerance and immunity. Annu Rev Immunol. 2008; 26: 677-704. PubMed Abstract | Publisher Full Text

87. Mellman I, Coukos G, Dranoff G: Cancer immunotherapy comes of age. Nature. 2011; 480(7378): 480-9.

PubMed Abstract | Publisher Full Text | Free Full Text

88. Patsoukis N, Brown J, Petkova V, et al.: Selective effects of PD-1 on Akt and Ras pathways regulate molecular components of the cell cycle and inhibit $\mathrm{T}$ cell proliferation. Sci Signal. 2012; 5(230): ra46.

PubMed Abstract | Publisher Full Text | Free Full Text

89. Pednekar L, Pathan AA, Paudyal B, et al:: Analysis of the Interaction between Globular Head Modules of Human C1q and Its Candidate Receptor gC1qR. Front Immunol. 2016; 7: 567.

PubMed Abstract | Publisher Full Text | Free Full Text

90. Li X, Eguchi T, Aly RG, et al.: Globular C1q Receptor (gC1qR/p32/HABP1) Is Overexpressed in Malignant Pleural Mesothelioma and Is Associated With Increased Survival in Surgical Patients Treated With Chemotherapy. Front Oncol. 2019; 9: 1042

PubMed Abstract | Publisher Full Text | Free Full Text

91. Yao ZQ, Eisen-Vandervelde A, Waggoner SN, et al:: Direct binding of hepatitis $\mathbf{C}$ virus core to $\mathrm{gC1qR}$ on $\mathrm{CD}^{+}$and $\mathrm{CD8}^{+} \mathrm{T}$ cells leads to impaired activation of Lck and Akt. $J$ Virol. 2004; 78(12): 6409-19.

PubMed Abstract | Publisher Full Text | Free Full Text

92. Peerschke El, Brandwijk RJ, Dembitzer FR, et al:: Soluble gC1qR in Blood and Body Fluids: Examination in a Pancreatic Cancer Patient Cohort. Int J Cancer Res Mol Mech. 2015; 1(3)

PubMed Abstract | Free Full Text

93. Peerschke EIB, Ghebrehiwet $\mathrm{B}$ : The contribution of $\mathrm{gC1qR} / \mathrm{p} 33$ in infection and inflammation. Immunobiology. 2007; 212(4-5): 333-42. PubMed Abstract | Publisher Full Text | Free Full Text

94. Ghebrehiwet B, Jesty J, Xu S, et al:: Structure-function studies using deletion mutants identify domains of $\mathrm{gC} 1 \mathrm{qR} / \mathrm{p} 33$ as potential therapeutic targets for vascular permeability and inflammation. Front Immunol. 2011; 2: 58. PubMed Abstract | Publisher Full Text | Free Full Text

95. da Costa PLN, Sirois $P$, Tannock IF, et al.: The role of kinin receptors in cancer and therapeutic opportunities. Cancer Lett. 2014; 345(1): 27-38. PubMed Abstract | Publisher Full Text

96. Stewart JM, Gera L: Bradykinin and Cancer. Handbook of Biologically Active Peptides. 2006; 443-446. Publisher Full Text

97. Chen J, Li GQ, Zhang L, et al.: Complement C5a/C5aR pathway potentiates the pathogenesis of gastric cancer by down-regulating p21 expression. Cancer the pathogenesis of $2018 ;$ 412: $30-6$. Lett. 2018; 412: 30-6.
PubMed Abstract | Publisher Full Text | Faculty Opinions Recommendation

98. Habermann JK, Roblick UJ, Luke BT, et al:: Increased serum levels of complement C3a anaphylatoxin indicate the presence of colorectal tumors. Gastroenterology. 2006; 131(4): 1020-9; quiz 1284.

PubMed Abstract | Publisher Full Text | Free Full Text

99. Maher SG, McDowell DT, Collins BC, et al:: Serum proteomic profiling reveals that pretreatment complement protein levels are predictive of esophageal cancer patient response to neoadjuvant chemoradiation. Ann Surg. 2011; 254(5): 809-16; discussion 816-7. PubMed Abstract | Publisher Full Text

100. Kourtzelis I, Rafail S: The dual role of complement in cancer and its implication in anti-tumor therapy. Ann Trans/ Med. 2016; 4(14): 265. PubMed Abstract | Publisher Full Text | Free Full Text

101. Massard C, Cassier P, Bendell JC, et al.: Preliminary results of STELLAR001, a dose escalation phase I study of the anti-C5aR, IPH5401, in combination with durvalumab in advanced solid tumours. Ann Oncol. 2019; 30: v492. Publisher Full Text | Faculty Opinions Recommendation 